\title{
Diagnosis Kelemahan Mahasiswa Teknik Menguasai Materi Fungsi Trasenden Menggunakan Program R
}

\author{
Munaji Munaji ${ }^{1, *}$, Suyitno Suyitno ${ }^{2)}$ \\ 1) Teknik Eelektro Universitas 17 Agustus 1945 Cirebon \\ 2) Teknik Mesin Universitas 17 Agustus 1945 Cirebon \\ *munaji@untagcirebon.ac.id
}

\begin{abstract}
Abstrak: Tujuan dari penelitian ini adalah untuk mengetahui kelemahan-kelemahan mahasiswa teknik dalam menguasai materi fungsi trasenden. Rancangan penelitian ini merupakan penelitian deskriptif kuantitatif. Instrumen penelitian berupa tes bentuk obyektif dengan empat pilihan jawaban. Teknik pengambilan sampel berupa teknik purposive sampling dengan jumlah sampel sebanyak 34 mahasiswa teknik elektro semester 2. Hasil analisis diagnostik menggunakan GDINA model program $\mathrm{R}$ menunjukkan bahwa kelemahan-kelemahan mahasiswa dalam menguasai materi fungsi tersenden yang paling dominan pada sub bab: (1) fungsi logaritma asli yaitu, mahasiswa belum menguasai penggunaan konsep logaritma asli dalam menyelesaikan masalah; (2) invers fungsi dan turunannya yaitu, mahasiswa belum menguasai bagaimana cara menentukan turunan dari invers fungsi dengan benar; (3) fungsi eksponen umum yaitu, mahasiswa belum menguasai bagaimana cara menentukan turunan dari fungsi eksponen asli dengan metode pendiferensialan implisit; (4) fungsi logaritma dan eksponen umum yaitu, mahasiswa belum menguasai bagaimana cara menggunakan sisfat-sifat fungsi eksponen umum dengan benar. Sub bab fungsi logaritma dan eksponen umum merupakan sub bab yang paling dominan belum dikuasai oleh mahasiswa dibandingkan dengan tiga sub bab lainnya.
\end{abstract}

Kata Kunci: Kelemahan Mahasiswa, Fungsi Trasenden, GDINA Model.

\section{PENDAHULUAN}

Hambatan-hambatan peserta didik dalam mempelajari matematika sangat lumrah terjadi. Penting untuk diketahui pada bagaian-bagian mana dari materi yang diajarkan masih belum dikuasai oleh peserta didik atau yang merupakan kelemahan peserta didik yang perlu ditingkatkan. Kesulitan belajar matematika bisa dialami pada hampir setiap jenjang pendidikan, bahkan pada orang dewasa (mahasiswa) sekalipun (Kumalasari and Sugiman 2015). Sebuah kondisi yang menunjukan hambatan-hambatan dalam mencapai kesulitan belajar merupakan suatu tanda terdapatnya kesulitan belajar yang dialami mahasiswa dan disamping itu kesulitan yang terdapat dalam pelajaran matematika memiliki ciri khas tersendiri dibanding mata pelajaran lain (Alyusfitri and Wahyuni 2017). Salah satu cara untuk mengetahui kelemahan peserta didik tersebut yaitu dengan melakukan analisis diagnostik kelemahan peserta didik.

Analisis diagnostik digunakan untuk mengetahui kekuatan dan kelemahan peserta didik dalam menyelesaikan serangkaian tes. Informasi hasil analisis diagnostik berkaitan dengan tidak menguasai atau menguasainya kompetensi tertentu yang diperlukan untuk menyelesaikan butir soal. Informasi tersebut berupa atribut yang mendasari soal, ketidaklengkapan atribut, dan kesalahan yang dilakukan peserta didik. Mengetahui bagian mana yang menjadi kelemahan peserta didik menjadi penting untuk direkomendasikan kepada stakeholders untuk meningkatkan kemampuan pendidik, mengembangkan pertanyaan, dan untuk meningkatkan proses pembelajaran matematika (Isgiyanto 2013).

Dalam sebuah sistem pendidikan, penilaian sudah menjadi kegiatan yang sangat penting yang harus dilaksanakan. Penilaian pendidikan memiliki beberapa keunggulan dan salah satu keunggulan tersebut adalah dalam bentuk adanya evaluasi (sumatif dan formatif), keputusan instruksional, seleksi, penempatan dan klasifikasi keputusan, keputusan kebijakan dan keputusan konseling dan bimbingan (Reynolds, Livingstone, and Wilson 2010). Keuntungan khusus dalam kaitannya dengan pemahaman kesulitan belajar siswa, dikenal sebagai 
diagnostik. Ada enam pendekatan penilaian diagnostik dalam kaitannya dengan masalah pembelajaran yaitu: (a) pendekatan kekuatan dan kelemahan pada kapasitas subjek; (b) pendekatan mengidentifikasi kelemahan pengetahuan prasyarat; (c) pendekatan mengidentifikasi tujuan pembelajaran yang belum dikuasai; (d) pendekatan mengidentifikasi kesalahan siswa; (e) pendekatan mengidentifikasi struktur pengetahuan siswa; dan (f) pendekatan identifikasi kompetensi untuk menyelesaikan item tes naratif (Nitko and Brookhart 2007).

Terdapat beberapa penelitian sebelumnya terkait diagnosis kesulitan belajar menggunakan CDM software $\mathrm{R}$, diantaranya adalah penelitian oleh Retnawawati (Retnawati 2017) yang bertujuan untuk mendiagnosis kesulitan peserta didik dalam menyelesaikan ujian nasional dengan metode penelitian deskriptif kuantitatif. Penelitian serupa juga dilakukan oleh Abdidin dan Retnawati (Abidin and Retnawati 2019) yang bertujuan untuk: (1) mengetahui karakteristik butir soal tes diagnostik materi lingkaran, (2) seberapa signifikan persentase jenis kesalahan siswa dalam menjawab soal, dan (3) diagnosa kesulitan siswa dalam menjawab soal berdasarkan model DINA dengan metode penelitian yang digunakan adalah metode deskriptif kuantitatif. Sementara itu, Ravand dan Robitzsch (Ravand and Robitzsch 2015) telah menerbitkan makalah mereka terkait penggunaan paket CDM dalam perangkat lunak $\mathrm{R}$ studio yang merupakan dasar-dasar penggunaan CDM untuk mendiagnosis kesulitan belajar peserta didik. Dengan demikian, kesamaan antara penelitian ini dengan penelitian yang dilakukan oleh Retnawati, Retnawati \& Abidin, serta Ravand dan Robitzsch, adalah menggunakan CDM sebagai alat untuk mendiagnosis kesulitan belajar peserta didik. Kesamaan lain dalam penelitian Retnawati dan Abdidin \& Retnawati terletak pada tujuan penelitian, subjek, dan metode penelitian, yang keduanya untuk mendiagnosis kesulitan belajar siswa pada bidang matematika menggunakan metode deskriptif. Perbedaannya dalam penelitian ini objek penelitiannya adalah tes matematika pada materi fungsi trasenden, sedangkan dalam penelitian Retnawati dan Abdidin \& Retnawati adalah masing-masing materi ujian nasional dan materi lingkaran.

Analisis diagnostik kesulitan mahasiswa dalam penelitian ini menggunakan Cognitive Diagnostic Modeling (CDM) dengan model GDINA pada program R Studio. G-DINA yang berarti Generalized the deterministic input, noise dan gate merupakan package/tools dari CDM. CDM adalah model psikometri yang dikembangkan terutama untuk menentukan kekuatan dan kelemahan spesifik peserta ujian, atau penguasaan atau tidak penguasaan seperangkat keterampilan atau atribut tertentu dalam suatu domain (Chen and Torre 2014). Melalui umpan balik diagnostik yang rinci, CDM dapat menginformasikan pengajar untuk memodifikasi kompetensi dasar dan proses pembelajaran di kelas (Ravand and Robitzsch 2015) agar lebih baik.

Mata kuliah kalkulus merupakan mata kuliah dasar yang sangat berguna sebagai alat analisis pada bidang teknik dan rekayasa. Fungsi trasenden merupakan salah satu pokok bahasan pada mata kuiah kalkulus menjadi penting karena mengkaji turunan dan integral untuk menggunakan kalkulus yang lebih luas. Penelitian ini dilatarbelakangi oleh laporan hasil penelitian Zamista (Zamista et al. 2020) yang menyatakan bahwa persepsi mahasiswa terhadap mata kuliah kalkulus cendrung ke arah negatif. Selain itu, berdasarkan laporan evaluasi proses pembelajaran pada ujian tengah semester (UTS) genap tahun 2020/2021, nilai rata-rata mahasiswa pada pokok bahasan fungsi trasenden masih belum memuaskan yang ditunjukkan dengan nilai rata-rata mahasiswa sebesar 49. Dari kedua latar belakang tersebut, untuk mengetahui kelemahan-kelemahan mahasiswa secara komperhensif maka tujuan penelitian kami adalah untuk melakukan analisis diagnostik kelemahan-kelemahan mahasiswa teknik dalam menguasai materi fungsi trasenden.

\section{METODE}

Rancangan penelitian ini merupakan rancangan penelitian deskriptif dengan pendekatan kuantitatif karena menggambarkan kelemahan mahasiswa teknik mempeljari materi fungsi trasenden, sehingga diperoleh kesimpulan yang kuat dan saling melengkapi tentang kesulitan belajar matematika. Subyek penelitian ini adalah mahasiswa prodi teknik elektro semester 2 sebanyak 34 mahasiswa. Teknik pengambilan sampel dalam penelitian ini teknik non-random sampling jenis purposive sampling, karena akan meneliti kelemahan mahasiswa teknik pada materi fungsi trasenden maka sampelnya adalah dipilih mahasiswa yang telah mengambil mata kuliah fungsi trasenden pada semester berjalan.

Instrumen penelitian berupa tes pilihan ganda dengan empat pilihan jawaban, terdiri dari 10 item soal pada mata kuliah kalkulus 1 Bab Fungsi Trasenden. Jawaban yang benar diberi skor 1 dan jawaban yang salah 
diberi skor 0 . Ada 4 sub bab yang dijujikan kepada mahasiswa yaitu: (1) fungsi logaritma asli, (2) fungsi invers dan turunannya, (3) fungsi eksponen asli, dan (4) fungsi logaritma dan eksponen umum.

Analisis data penelitian yang digunakan dalam penelitian ini adalah CDM dengan model GDINA menggunakan program R. R adalah bahasa pemrograman dan perangkat lunak untuk analisis statistik dan grafis. Bahasa R sekarang menjadi standar de facto di antara ahli statistik untuk pengembangan perangkat lunak statistik, dan secara luas digunakan untuk pengembangan perangkat lunak statistik dan analisis data. Langkah-langkah mendiagnosis kelemahan mahasiswa dalam belajar matematika pada bab fungsi trasenden mengacu pada langkah-langkah analisis melalui penerapan CDM yang telah dikemukakan oleh Ravand dan Robitzch yaitu: merancang spesifikasi atribut, menganalisis butir soal dan melihat hubungannya dengan Q-Matrix, membangun hubungan antara sub-keterampilan dan penguasaan keterampilan penguasaan peserta tes melalui CDM (Ravand and Robitzsch 2015). Berdasarkan langkah-langkah tersebut, 10 butir soal tes akan dibagi menjadi 4 Q-Matriks menyesuaikan sub bab pokok bahasan pada fungsi trasenden. Analisis dilakukan dengan mengimplementasikan paket CDM dan GDINA model dari program $\mathrm{R}$ yang menghasilkan atribut laten. Selanjutnya atribut-atribut tersebut akan diinterpretasikan dan interpretasinya meliputi kelemahan-kelemahan paling dominan mahasiswa terhadap atribut/item yang seharusnya dikuasai. Analisis lanjutan dilakukan untuk melihat pada sub bab mana dari 4 sub bab pada bab fungsi trasenden yang paling dominan belum dikuasai oleh mahasiswa. Sedangkan analisis model fit digunakan untuk melihat kecocokan penggunaan model bila dibandingkan dengan model lain yang sejenis. Dalam hal ini GDINA dibandingkan model DINA yang keduanya sama merupakan packege dari CDM.

File data Q-Matriks dan jawaban mahsiswa yang akan dianalisis menggunakan $\mathrm{R}$ harus disimpan dalam ekstensi .csv pada microsoft excel. Sebagai contoh untuk jawaban mahasiswa pada sub bab fungsi logritma asli diberi nama "jawaban1" sementara untuk Q-Matriks dari dari bab fungsi trasenden diberi nama "Q1-Matriks". File data .csv tersebut kemudian diimpor ke program R-Studio. Selanjutnya adalah memulai menggunakan package CDM dan GDINA pada program R.

Berikut adalah langkah-langkah untuk mendapatkan data output kelemahan-kelemahan peserta tes terhadap setiap atribut pada Q-Matriks (analisis pertama menggunakkan nama "analisis1"):

$>$ library(CDM)

$>$ library(GDINA)

$>$ analisis $1<$-gdina(data=jawaban1, q.mat=Q1.matriks)

$>$ analisis 1 \$attribute.patt

Untuk melihat pada sub bab mana dari 4 sub bab fungsi trasenden yang paling dominan belum dikuasai mahasiswa, dengan CDM dan GDINA masih dalam keadaan aktif, maka bahasa pemrograman yang digunakan adalah sebagai berut:

$>$ analisis $5<$-gdina(data=jawaban1, q. mat=Q1. matriks)

$>$ analisis $5 \$$ skill.patt

Untuk melihat kecocokan penggunaan GDINA untuk analisis data penelitian ini, dengan CDM dan GDINA masih dalam keadaan aktif, maka bahasa pemrograman yang digunakan adalah sebagai berikut:

$>$ analisis6 <- gdina(data=jawaban1, q. mat=Q1.matriks)

$>$ IRT.modelfit(analisis6)

Sedangkan untuk mendapatkan output model fit dari model DINA, dengan CDM dan GDINA masih dalam keadaan katif, maka bahasa pemrograman yang digunakan adalah sebagai berikut:

$>$ library(dina)

$>$ analisis $7<$ - din(jawaban, q.mqtriks_jawaban)

$>$ IRT.modelfit(analisis7)

\section{HASIL DAN PEMBAHASAN}

Analisis hasil dan pembahasan penelitian disajikan menjadi beberapa bagian, yaitu Q1-Matriks terkait dengan sub pokok bahasan logaritma asli, Q2-Mtriks terkait dengan sub pokok bahasan fungsi invers dan turunannya, Q3-Mtriks terkait dengan pokok bahasan eksponen asli, Q4-Matriks terkaiit dengan sub pokok 
bahasan logaritma umum dn eksponen umu. Selain itu, analisis juga menyajikan hasil diagnosis pada sub pokok bahasan yang paling dominan belum dikuasi mahasiswa. Hasil penelitian juga menyajikan pemeriksaan moodel fiti yang digunakan untuk melihat kecocokan model GDINA untuk analisis data penelitian ini.

\section{Q1-Matriks: Logaritma Asli}

Q1 matriks terdiri dari 4 item tes, yaitu item 1, 2, 3, dan 4. Item-item tersebut memiiki atribut-atribu sebagai berikut: (A1) dapat menurunakn fungsi logaritma asli, (A2) dapat mengintegralkan fungsi lgaritma asli, (A3) penggunaan konsep fungsi logaritma asli dalam menyelesaikan masalah, (A4) dapat menurunkn fungsi kontanta fungsi logaritma asli. Atribut dan item Q1-Matriks disajikan pada Tabel 1.

Tabel 1. Item dan Atribut Q1-Matriks

\begin{tabular}{ccccc}
\hline \multirow{2}{*}{ Item } & \multicolumn{5}{c}{ Attribute: } \\
\cline { 2 - 5 } & A1 & A2 & A3 & A4 \\
\hline 1 & 1 & 0 & 0 & 0 \\
2 & 0 & 1 & 0 & 0 \\
3 & 0 & 0 & 1 & 0 \\
4 & 0 & 0 & 0 & 1 \\
\hline
\end{tabular}

Berdasarkan 4 atribut pada Tabel 1 , maka banyaknya kelas laten yang mungkin adalah $2^{4}=16$. Class Probabilities yang menunjukkan kelemahan dan keunggulan subyek penelitian terkait penguasaan sub pokok bahasan fungsi logaritma asli disajikan pada Tabel 2.

Tabel 2. Class Probability of Q1-Matriks

\begin{tabular}{cccc}
\hline Latent Clasis $(\alpha)$ & Attribute Profile & Class Probability & Class Excpected Frequency \\
\hline 1 & 0000 & 0,0501 & 1.7034 \\
2 & 1000 & 0.0000 & 0.000 \\
3 & 0100 & 0.0000 & 0.000 \\
4 & 1100 & 0.0000 & 0.0000 \\
5 & 0010 & 0.0000 & 0.9996 \\
6 & 1010 & 0.0000 & 0.0000 \\
7 & 0110 & 0.1472 & 5.0048 \\
8 & 1110 & 0.0095 & 0.3230 \\
9 & 0001 & 0.0382 & 1.2988 \\
10 & 1001 & 0.2352 & 7.9968 \\
11 & 0101 & 0.0000 & 0.0000 \\
12 & 1101 & 0.1471 & 5.0014 \\
13 & 0011 & 0.0000 & 0.0000 \\
14 & 1011 & 0.0000 & 0.0000 \\
15 & 0111 & 0.0000 & 0.0000 \\
16 & 1111 & 0.0000 & 0.0000 \\
\hline
\end{tabular}

Dari Tabel 3 dapat dijelaskan bahwa pada kelas laten $\alpha_{10}\left(\begin{array}{llll}1 & 0 & 0 & 1\end{array}\right)$ memiliki class probability paling dominan yaitu 0.2352 . Artinya sebanyak 23,52 \% atau sekitar 7 responden belum menguasai atribut (A2) dan (A3). Pada kelas laten $\alpha_{7}\left(\begin{array}{llll}0 & 1 & 1 & 0\end{array}\right)$ memiliki class probability sebesar 0.1472 . Jadi sebanyak $14,72 \%$ atau sekitar 5 responden belum menguasai atribut (A1) dan (A4). Berdasarkan nilai class probability pada kelas laten $\alpha_{12}\left(\begin{array}{llll}1 & 1 & 0 & 1\end{array}\right)$ memiliki class probability sebesar 0.1471 . Jadi sebanyak $14,71 \%$ atau 5 responden belum menguasai atribut (A3) dan berdasarkan kelas laten $\alpha_{1}\left(\begin{array}{llll}0 & 0 & 0 & 0\end{array}\right)$ memiliki class probability sebesar 0.0501 . jadi sebanyak $5.01 \%$ atau sekitar 2 responden belum menguasai satupun atribut pada Q1-Matriks. Dengan demikian atribut yang paling dominan belum dikuasai oleh responden adalah atribut (A3) yang artinya responden belum menguasai penggunaan konsep logaritma asli dalam menyelesaikan masalah.

Atribut A3 yang paling dominan belum dikuasi oleh mahasiswa terkait dengan penggunaan konsep fungsi logaritma dan eksponen asli dalam menyelesaikan masalah disajikan pada Gambar 1.

Contoh soal pada Gambar 1 merupakan penggunaan dari fungsi logaritma asli. Soal tersebut merupakan soal aplikasi yang tingkat kesulitannya relatif lebih tinggi. Perlu keterampilan problem solving bagi peserta tes selain 
juga menguasai konsep yang digunakan untuk menyeleseikan masalah pada soal tersebut. Bisa jadi mahasiswa kurang memiliki keterampilan problem solving yang baik sehingga masih lemah pada materi penggunaan konsep logaritma asli ini.

$$
\begin{aligned}
& \text { Suatu kelompok bakteri bertumbuh dan laju yang sebanding dengan } \\
& \text { besarnya kelompok itu. Pada awal ada } 10.000 \text { dan setelah } 10 \text { hari kelompok } \\
& \text { itu terdiri atas } 24.000 \text { bakteri. Berapakah banyaknya bakteri setelah } 25 \text { hari? } \\
& \text { a. } 89.432 \text { bakteri } \\
& \text { b. } 98.234 \text { bakteri } \\
& \text { c. } 89.234 \text { bakteri } \\
& \text { d. } 98.123 \text { bakteri }
\end{aligned}
$$$$
\text { besarnya kelompok itu. Pada awal ada } 10.000 \text { dan setelah } 10 \text { hari kelompok }
$$

Gambar 1. Contoh Soal Terkait Penggunaan Konsep Fungsi logaritma dan Eksponen Asli dalam Menyelesaikan Masalah

\section{Q2-Matriks: Invers Fungsi dan Turunannya}

Q2 matriks terdiri dari 2 item tes, yaitu item 5 dan 6. Item-item tersebut memiiki atribut-atribut sebagai berikut: (A5) dapat menentukan invers fungsi dari sebuah fungsi, (A6) dapat menentukan turunan dari invers fungsi. Atribut dan item Q2-Matriks disajikan pada Tabel 3.

Tabel 3. Item dan Atribut Q1-Matriks

\begin{tabular}{ccc}
\hline \multirow{2}{*}{ Item } & \multicolumn{2}{c}{ Attribute: } \\
\cline { 2 - 3 } & $\mathrm{A} 1$ & $\mathrm{~A} 2$ \\
\hline 5 & 1 & 0 \\
6 & 0 & 1 \\
\hline
\end{tabular}

Berdasarkan 2 atribut pada Tabel 2, maka banyaknya kelas laten yang mungkin adalah $2^{2}=4$. Class Probabilities yang menunjukkan kelemahan dan keunggulan subyek penelitian terkait penguasaan sub pokok bahasan invers fungsi dan turunannya diajikan pada Tabel 4.

Tabel 4. Class Probability of Q2-Matriks

\begin{tabular}{cccc}
\hline Latent Clasis $(\alpha)$ & Attribute Profile & Class Probability & Class Excpected Frequency \\
\hline 1 & 00 & 0.2111 & 7.1767 \\
2 & 10 & 0.5458 & 18.5558 \\
3 & 01 & 0.2430 & 8.2626 \\
4 & 11 & 0.0001 & 0.0046 \\
\hline
\end{tabular}

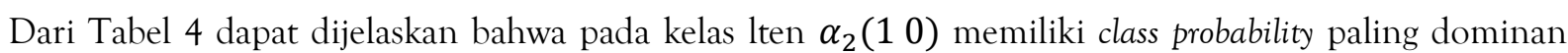
yaitu 0.5458 . Artinya sebanyak 54,58 \% atau sekitar 18 responden belum menguasai atribut (A5). Pada kelas laten $\alpha_{1}\left(\begin{array}{l}0 \\ 0)\end{array}\right)$ memiliki class probability sebesar 0.2111 . Sebanyak $21,11 \%$ atau sekitar 7 responden belum menguasai satupun atribut pada Q2-Mtriks. Berdasarkan nilai class probability pada kelas laten $\alpha_{1}\left(\begin{array}{l}0 \\ 0\end{array}\right)$ dan $\alpha_{2}\left(\begin{array}{ll}1 & 0\end{array}\right)$ maka dapat dikatakan bahwa atribut yang paling dominan belum dikuasai oleh responden adalah atribut (A6) yang artinya responden belum menguasai bagaimana cara menentukan turunan dari invers fungsi dengan benar.

Atribut A6 yang paling dominan belum dikuasi oleh mahasiswa terkait dengan turunan dan invers fungsi disajikan pada Gambar 2.

Turunan invers fungsi dari $f(x)=5 x+6$ adalah ....
a. $\frac{x-6}{5}$
c. $\frac{1}{5}$
b. $\frac{1}{5}(x-6)$
d. $\frac{1}{6}$

Gambar 2. Contoh Soal Terkait Turunan dari Invers Fungsi 
Agar dapat menjawab contoh soal pada Gambar 2, responden harus mampu menentukan invers fungsinya terlebih dahulu dan hasilnya kemudian diturunkan. Dengan demikian ada dua langkah esensial untuk sampai bisa menemukan jawaban benarnya.

\section{Q3-Matriks : Fungsi Eksponen Asli}

Q3 matriks terdiri dari 2 item tes, yaitu item 7 dan 8. Item-item tersebut memiiki atribut-atribut sebagai berikut: (A7) dapat menentukan turunan dari fungsi eksponen asli, (A8) dapat menentukan turunan dari fungsi eksponen asli dengan metode pendiferensialan implisit. Atribut dan item Q3-Matriks disajikan pada Tabel 5.

Tabel 5. Item dan Atribut Q1-Matriks

\begin{tabular}{ccc}
\hline \multirow{2}{*}{ Item } & \multicolumn{2}{c}{ Attribute: } \\
\cline { 2 - 3 } 7 & A1 & A2 \\
8 & 1 & 0 \\
8 & 0 & 1 \\
\hline
\end{tabular}

Berdasarkan 2 atribut pada Tabel 5, maka banyaknya kelas laten yang mungkin adalah $2^{2}=4$. Class Probabilities yang menunjukkan kelemahan dan keunggulan subyek penelitian terkait penguasaan sub pokok bahasan fungsi eksponen asli diajikan pada Tabel 6.

Tabel 6. Class Probability of Q2-Matriks

\begin{tabular}{cccc}
\hline Latent Clasis $(\alpha)$ & Attribute Profile & Class Probability & Class Excpected Frequency \\
\hline 1 & 00 & 0.2276 & 7.7382 \\
2 & 10 & 0.3253 & 11.0621 \\
3 & 01 & 0.2194 & 7.4616 \\
4 & 11 & 0.2276 & 7.7381 \\
\hline
\end{tabular}

Dari Tabel 6 dapat dijelaskan bahwa pada kelas laten $\alpha_{4}\left(\begin{array}{ll}1 & 1\end{array}\right)$ dengan class probability sebesr 0.2276 meunjukkan bahwa baru sebagian kecil yaitu 22,67\% atau sekitar 7 responden yang sudah menguasai semua atribut pada Q3-Matriks. Pada kelas laten $\alpha_{2}\left(\begin{array}{ll}1 & 0\end{array}\right)$ memiliki class probability paling dominan yaitu 0.3253. Artinya sebanyak 52,53\% atau sekitar 11 responden belum menguasai atribut (A7). Pada kelas laten $\alpha_{1}(00)$ memiliki class probability sebesar 0.2276 . Jadi sebanyak $21.76 \%$ atau sekitar 7 responden belum menguasai satupun atribut pada Q3-Mtriks. Berdasarkan nilai class probability pada kelas laten $\alpha_{1}\left(\begin{array}{ll}0 & 0\end{array}\right)$ dan $\alpha_{2}\left(\begin{array}{ll}1 & 0\end{array}\right)$ maka dapat dikatakan bahwa atribut yang paling dominan belum dikuasai oleh responden adalah atribut (A8) yang artinya responden belum menguasai bagaimana cara menentukan turunan turunan dari fungsi eksponen asli dengan metode pendiferensialan implisit.

Atribut A8 yang paling dominan belum dikuasi oleh mahasiswa terkait dengan turunan fungsi eksponen asli dengan metode turunan fungsi implisit disajikan pada Gambar 3 di bawah ini.

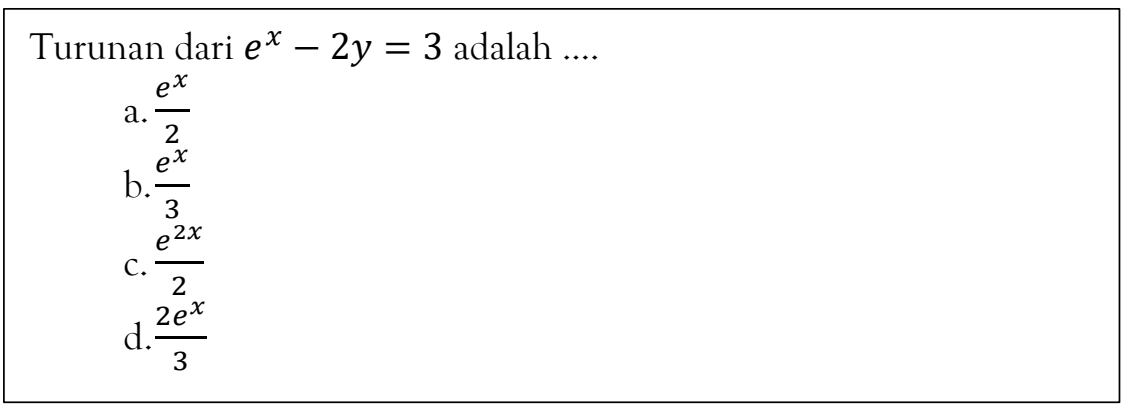

Gambar 3. Contoh Soal Terkait Turunan Fungsi Eksponen Asli dengan Metode Turunan Fungsi Implisit

Agar dapat menjawab contoh soal pada Gambar 3, responden harus mampu menguasai metode pendiferensialan implisit. Metode pendiferensialan implisit adalah pencarian $d y / d x$ tanpa terlebih dahulu menyelesaikan persamaan yang diberikan untuk y secara gamblang dalam bentuk $x$ (Purcell and Varberg 1987). Metode ini digunakan untuk menurunkan fungsi-fungsi implisit yang tidak bisa diuraikan menjadi fungsi eksplisit. Dalam menggunakan metode pendiferensialan implisit beberapa konsep perlu dikuasai sekaligus misalnya konsep turunan dengan rumus dasar turunan dan aturan rantai. Kelemahan mahasiswa bisa jadi 
disebabkan oleh belum menguasainya metode pendiferensialan fungsi implisit. Nampaknya mereka melihait soal ini nampak seperti fungsi eksponen asli pada umumnya.

\section{Q4-Matriks : Fungsi Logaritma dan Eksponen Umum}

Q4 matriks terdiri dari 2 item tes, yaitu item 9 dan 10. Item-item tersebut memiiki atribut-atribut sebagai berikut: (A9)dapat menggunakan sifat-sifat fungsi logaritma umum dan (A10) dapat menggunakan sifat-sifat eksponen umum. Atribut dan item Q4-Matriks disajikan pada Tabel 7.

Tabel 7. Item dan Atribut Q1-Matriks

\begin{tabular}{ccc}
\hline \multirow{2}{*}{ Item } & \multicolumn{2}{c}{ Attribute: } \\
\cline { 2 - 3 } 9 & A1 & A2 \\
9 & 1 & 0 \\
10 & 0 & 1 \\
\hline
\end{tabular}

Berdasarkan 2 atribut pada Tabel 7, maka banyaknya kelas laten yang mungkin adalah $2^{2}=4$. Class Probabilities yang menunjukkan kelemahan dan keunggulan subyek penelitian terkait penguasaan sub pokok bahasan fungsi logaritma umum dan fungsi eksponen umum disajikan pada Tabel 8.

Tabel 8. Class Probability of Q4-Matrixs

\begin{tabular}{cccc}
\hline Latent Clasis $(\alpha)$ & Attribute Profile & Class Probability & Class Excpected Frequency \\
\hline 1 & 00 & 0.2685 & 9.1302 \\
2 & 10 & 0.3373 & 11.4698 \\
3 & 01 & 0.1961 & 6.6695 \\
4 & 11 & 0.1979 & 6.7303 \\
\hline
\end{tabular}

Dari Tabel 8 dapat dijelaskan bahwa pada kelas laten $\alpha_{4}(11)$ dengan class probability sebesr 0.1979 meunjukkan bahwa baru sebagian kecil yaitu 19,79\% atau sekitar 6 responden yang sudah menguasai semua atribut pada Q4-Matriks. Pada kelas laten $\alpha_{2}\left(\begin{array}{ll}1 & 0\end{array}\right)$ memiliki class probability paling dominan yaitu 0.3373. Artinya sebanyak 33,73\% atau sekitar 11 responden belum menguasai atribut (A10). Pada kelas laten $\alpha_{1}(00)$ memiliki class probability sebesar 0.2685 . Jadi sebanyak $26.85 \%$ atau sekitar 9 responden belum menguasai satupun atribut pada Q4-Mtriks. Berdasarkan nilai class probability pada kelas laten $\alpha_{1}\left(\begin{array}{l}0 \\ 0\end{array}\right)$ dan $\alpha_{2}\left(\begin{array}{ll}1 & 0\end{array}\right)$ maka dapat dikatakan bahwa atribut yang paling dominan belum dikuasai oleh responden adalah atribut (A10) yang artinya responden belum menguasai bagaimana cara menggunakan sisfat-sifat fungsi eksponen umum dengan benar.

Atribut A10 yang paling dominan belum dikuasai oleh mahasiswa terkait dengan fungsi eksponen umum disajikan pada Gambar 4 di bawah ini.

Turunan dari $4^{x^{3}}=\cdots$
a. $\ln (2) \cdot 2^{2 x^{3}+1} x^{3}$
b. $3 \ln (2) \cdot 2^{2 x^{3}+1} x^{2}$
c. $3 x^{2} \ln (2) \cdot 2^{2 x^{3}+1}$
d. $2 x^{2}(2) \cdot 2^{2 x^{3}+1}$

Gambar 4. Contoh Soal Terkait dengan Fungsi Eksponen Umum

Penyelesaian contoh soal pada Gambar 4 memerlukan langkah-langkah yang kompleks. Mulai dari (1) menggunakan aturan eskponen $\mathrm{a}^{\mathrm{b}}=e^{\mathrm{b} \ln \mathrm{a}},(2)$ aturan rantai, dan (3) menyederhanakan. Tentu soal ini memrlukan pemikiran yang cukup keras.

\section{Analisis Kelemahan pada Sub-Bab}

Untuk melihat pada sub bab mana dari 4 sub bab fungsi trasenden pada penelitian ini yang paling dominan belum dikuasai mahasiswa dilakukan analisis attribut skill yang hasilnya ditunjukkan oleh Tabel 9. 
Tabel 9. Kelemahan Atribut

\begin{tabular}{lcc}
\hline Atribut & Prob. (0) Skill & Prob (1) Skill \\
\hline Logaritma Asli & 0.35 & 0.65 \\
Eksponen Asli & 0.53 & 0.47 \\
Invers Fungsi dan Turunannya & 0.53 & 0.47 \\
Logaritma dan Eksponen Umum & 0.60 & 0.40 \\
\hline
\end{tabular}

Dari Tabel 9 kolom 3 dapat dijelaskan bahwa atribut logaritma asli telah dikuasai oleh 65\% responden. Sedangkan atribut eksponen asli, atribut inevers fungsi dan turunannya, atribut logaritma dan eksponen umum telah dikuasai oleh responden berturut-turut oleh 47\%, 47\%, dan 40\% responden. Dengan demikian dapat jelaskan bahwa atribut yang paling mudah dikuasai responden adalah atribut logaritma asli, sedangkan atribut yang paling susah dikuasi responden adalah atribut logaritma dan eksponen umum.

\section{Kecocokan Model (Model Fit)}

Model fit digunakan untuk melihat kecocokan penggunaan model bila dibandingkan dengan model lain yang sejenis. Seperti dalam model statistik lainnya, parameter estimasi dalam CDM dapat ditafsirkan sejauh bahwa model tersebut cocok dengan data. Kecocokan model bisa dilakukan dalam dua cara, yaitu: (1) memeriksa kecocokan model untuk data (yaitu, kecocokan mutlak) dan (2) membandingkan model dengan model rivalnya (yaitu, kecocokan relatif). Dalam penelitian ini paket CDM menggunakan model GDINA menghasilkan rentang indeks kecocokan mutlak dengan membandingkan respons yang diamati dan diprediksi model frekuensi pasangan item. Indeks kecocokan absolut dan relatif tersebut diperoleh dengan menjalankan perintah "IRT.modelfit()". Pada penelitian ini pemeriksaan kecocokan model menggunakan metode kecocokan relatif yang hasilnya ditunjukkan pada Tabel 10.

Tabel 10. Kecocokan Model GDINA

\begin{tabular}{|c|c|c|c|c|c|c|c|c|c|c|}
\hline Model & Loglike & deviance & Npars & Nobs & AIC & BIC & AIC3 & AICc & CAIC & maxX2 \\
\hline gdin & -188.9069 & 377.8138 & 31.0000 & 34.0000 & 439.8138 & 487.1310 & 470.8138 & 1431.8138 & 518.1310 & 11.46706 \\
\hline dina & -188.9019 & 377.8039 & 35.0000 & 34.0000 & 447.8039 & 501.2265 & 482.8039 & -812.1961 & 536.2265 & 11.46804 \\
\hline
\end{tabular}

Dari Tabel 10 dapat dijelaskan nampak indeks kecocokan relatif dari kriteria informasi AIC, BIC, AIC3, ukuran sampel AIC yang disesuaikan (AICc) dan maxX2. Model dengan kriteria informasi nilai paling kecil adalah model yang lebih baik (Ravand and Robitzsch 2015). Ternyata model GDINA merupakan model terbaik pada semua kriteria. Dengan demikian model GDINA lebih baik dari model DINA.

\section{SIMPULAN}

Kelemahan-kelemahan mahasiswa dalam menguasai materi fungsi tersenden yang paling dominan pada sub bab: (1) fungsi logaritma asli yaitu, mahasiswa belum menguasai penggunaan konsep logaritma asli dalam menyelesaikan masalah; (2) invers fungsi dan turunannya yaitu, mahasiswa belum menguasai bagaimana cara menentukan turunan dari invers fungsi dengan benar; (3) fungsi eksponen umum yaitu, mahasiswa belum menguasai bagaimana cara menentukan turunan dari fungsi eksponen asli dengan metode pendiferensialan implisit; (4) fungsi logaritma dan eksponen umum yaitu, mahasiswa belum menguasai bagaimana cara menggunakan sisfat-sifat fungsi eksponen umum dengan benar. Sub bab fungsi logaritma dan eksponen umum merupakan sub bab yang paling dominan belum dikuasai oleh mahasiswa dibandingkan dengan tiga sub bab lainnya pada materi fungsi trasenden yang diujikan.

\section{Ucapan Terima Kasih}

Terima kasih disampikan kepda mahasiswa semester 3 Prodi Teknik Elektro Universitas 17 Agustsus 1945 Cirebon tahun akademik 2020/2021 yang telah menjadi responden penelitian ini. 


\section{Daftar Pustaka}

Abidin, Minhajjul, and Heri Retnawati. 2019. "A Diagnosis of Difficulties in Answering Questions of Circle Material on Junior High School Students.” Jurnal Penelitian Dan Evaluasi Pendidikan 23(2). doi: $10.21831 /$ pep.v23i2.16454.

Alyusfitri, Rieke, and Yusri Wahyuni. 2017. Analisis Diagnostik Kesulitan Belajar Mahasiswa PGSD Pada Mata Kuliah Konsep Dasar Matematika II. Vol. 8.

Chen, Jinsong, and Jimmy de la Torre. 2014. "A Procedure for Diagnostically Modeling Extant LargeScale Assessment Data: The Case of the Programme for International Student Assessment in Reading.” Psychology 05(18). doi: 10.4236/psych.2014.518200.

Isgiyanto, Awal. 2013. "Diagnosis Kesalahan Siswa Berbasis Penskoran Politomus Model Partial Credit Pada Matematika." Jurnal Penelitian Dan Evaluasi Pendidikan 15(2). doi: 10.21831/pep.v15i2.1099.

Kumalasari, Ade, and Sugiman Sugiman. 2015. Analisis Kesulitan Belajar Mahasiswa Pada Mata Kuliah Kapita Selekta Matematika Sekolah Menengah. Vol. 2.

Nitko, A. J., and S. M. Brookhart. 2007. Educational Assessment of Students. Boston: earson Merrill Prentice Hall.

Purcell, Edwin J., and Dale Varberg. 1987. Kalkulus Dan Geometri Analitis. Vol. 1. 1st ed. Jakarta: Erlangga.

Ravand, Hamdollah, and Alexander Robitzsch. 2015. "Cognitive Diagnostic Modeling Using R.” Practical Assessment, Research and Evaluation 20(11):1-12.

Retnawati, Heri. 2017. "Diagnosing The Junio High School Student's Difficulties In Learning Mathematics." International Journal on New Trends in Education and Their Implications 8(1):33-50.

Reynolds, C. R., R. B. Livingstone, and V. Wilson. 2010. Measurement and Assessment in Education (2 $\mathrm{Nd}$ Ed.). 2nd ed. London: Pearson.

Zamista, Adelia Alfama, Rahmi Hanifatul, Ari Sellyana, and Welly Desriyati. 2020. "Persepsi Mahasiswa terhadap Pembelajaran Dalam Jaringan untuk Mata Kuliah Kalkulus.” The Original Research of Mathematics) 5(1):41-48. 